\title{
Structural Features of the Vegetative Organs of Allium praemixtum Vved. in Different Ecological Conditions
}

\author{
Akida T. Abdullaeva1 ${ }^{*}$, Guljan M. Duschanova1, Muhabbat H. Ravshanova ${ }^{2}$ \\ ${ }^{1}$ Laboratory Anatomy and Cytoembryology of the Tashkent Botanical Garden Named after Academician F. N. Rusanov, Institute \\ of Botany of the Academy of Sciences, Tashkent, Uzbekistan \\ ${ }^{2}$ Department of Biology Educations, Faculty of Natural Sciences, Navoi State Pedagogical Institute, Navoiy, Uzbekistan \\ Email: *guljon.duschanova@mail.ru
}

How to cite this paper: Abdullaeva, A.T., Duschanova, G.M. and Ravshanova, M.H. (2019) Structural Features of the Vegetative Organs of Allium praemixtum Vved. in Different Ecological Conditions. American Journal of Plant Sciences, 10, 536-544. https://doi.org/10.4236/ajps.2019.104038

Received: February 25, 2019

Accepted: April 14, 2019

Published: April 17, 2019

Copyright $\odot 2019$ by author(s) and Scientific Research Publishing Inc. This work is licensed under the Creative Commons Attribution International License (CC BY 4.0).

http://creativecommons.org/licenses/by/4.0/

\section{Open Access}

\begin{abstract}
Central Asia is one of the main centers of origin of bulbous geophytes, including the family Amaryllidaceae Juss. The anatomical features of many endemic, red-book bulbous geophytes are still poorly understood. The article presents the results of a structural study of the inflated part of the stem (fistular), stem and pedicels of an endemic $A$. praemixtum species grow in two different environmental conditions in the Aktau mountain Nurata Range (Uzbekistan, Province Navoi) and in the conditions of introduction in the Tashkent Botanical Garden (Uzbekistan, Tashkent city). Diagnostic signs of vegetative organs were revealed and various combinations of xeromorphic and mesomorphic signs were determined. Comparative anatomical study of vegetative organs of $A$. praemixtum is of great theoretical and practical importance in relation to taxonomy and ecology.
\end{abstract}

\section{Keywords}

Anatomy, Vegetative Organs, Allium praemixtum, Navoi Region,

Introduction, Tashkent Botanical Garden, Uzbekistan

\section{Introduction}

The study of endemic, rare, Red Book plant species is an urgent task today. In this regard, we have undertaken a study of the structure of endemics-a representative of the genus Allium L. According to modern data, the genus Allium L. unites more than 800 - 900 species distributed in the Northern Hemisphere [1]. In an independent family, the genus Allium was first identified by J.G. Agardh 
[2]. He combined a genus with strongly odorous substances, ally disulfides [3]. The independence of Alliaceae was proved by A.L. Takhtajan [4].

Because of the taste and aromatic qualities, some species of onions have long been introduced into culture, but in many localities the population eats wild species. The garlic smell and taste of onions are caused by garlic oil in all tissues, the main part of which is disulfide-which contains a lot of sulfur [5].

Many onion representatives are edible, medicinal and decorative. In the food onion-A. cepa L. found some useful substances: essential oil (up to $0.05 \%$ ), sugar $(10 \%-11 \%)$, consisting of glucose, fructose, sucrose and maltose inulin. The leaves have vitamins-C (20 mg \%), $\mathrm{B}_{2}(50 \mathrm{mg} \%)$, provitamin A (4 mg \%), citric and apple acids [6]. Some species of onions are different highly decorative (A. giganteum, A. christophii, A. coeruleum) and are heavily requested by foreign flower companies [5].

\section{Materials and Methods}

Allium praemixtum Vved is a perennial, red-book, rare endemic bulbous plant with a status of $1[7]$.

The material was collected at the beginning of June 2018 from natural conditions growth in the Aktau mountain Nurata Range (Uzbekistan, Province Navoi) and in the conditions of introduction in the Tashkent Botanical Garden (Uzbekistan, Tashkent city). Aktau - the remnant mountain, part of the Tamdytau mountain system (the northern part of Tamdytau), consists of Silurian dolomitized limestone ridges with steep slopes. Length—about $20 \mathrm{~km}$, height-974 m above sea level with a rather dissected relief [8]. Tashkent Botanical Garden is geographically located in the northeastern part of Tashkent, at an altitude of 473.3 meters above sea level; Chirchik in the low adyr belt at an altitude of 450 $480 \mathrm{~m}$ above sea level. The climate is sharply continental. The average annual precipitation during the study was $337 \mathrm{~mm}$, the average annual temperature $13.8^{\circ} \mathrm{C}$. Precipitation falls mainly in the autumn-winter and spring periods; soil cultural-irrigated gray soils or irrigated sierozem [9].

The vegetative organs (inflated part of stem (fistular), stem and pedicels) from the middle layer in the beginning of flowering period were examined. Morphological description and phenological observations were carried out in natural habitats and in the conditions of introduction. Vegetative organs were fixed in $70 \%$ ethanol. The type of inflated part of stem (fistular), stem and pedicels mesophyll was defined on cross sections through the middle part. The sections were made by razor, imbued with methylene blue, and were sealed in glycerol-gelatine. The studied tissues and cells are given according to K. Esau [10], N. S. Kiseleva [11]. The measurements were carried out according to the standard method [12]. The measurements were carried out in the tissues and cells of plants in 30 times repetition using an MOV-1-15x eyepiece micrometer. The micrographs of preparations were made with a Canon $A 123$ digital camera under the microscope Motic B 1-220A-3. The measurements were carried out in 
thirtyfold replicates, calculated in average value, measurement errors and significance by Zaitsev's formula [13] using a personal computer (MS-Excel program).

\section{Results and Discussion}

The structure of the inflated part of stem (fistular) of $A$. praemixtum in conditions growth in the Aktau mountain, Nurata Range (Uzbekistan, Province Navoi): On the cross section of a round shape. The structure of the parenchymal-bundle type. The epidermis consists of a single row of cells, elongated oval, with a large diameter of $54.9 \pm 0.37 \mu \mathrm{m}$ in height. The walls of the outer epidermis are thick-23.1 $\pm 0.18 \mu \mathrm{m}$.

The stoma is numerous, slightly immersed $-19.2 \pm 0.09 \mu \mathrm{m}$. Under the epidermis is located 6 - 7 row round-oval, macro cellular cortex parenchyma with a diameter of $126.3 \pm 1.13 \mu \mathrm{m}$, underneath there are single-row, few large lacteals with a diameter of $35.1 \pm 0.21 \mu \mathrm{m}$, which are localized through each $2-3$ cortex parenchyma (Figure 1; Table 1).
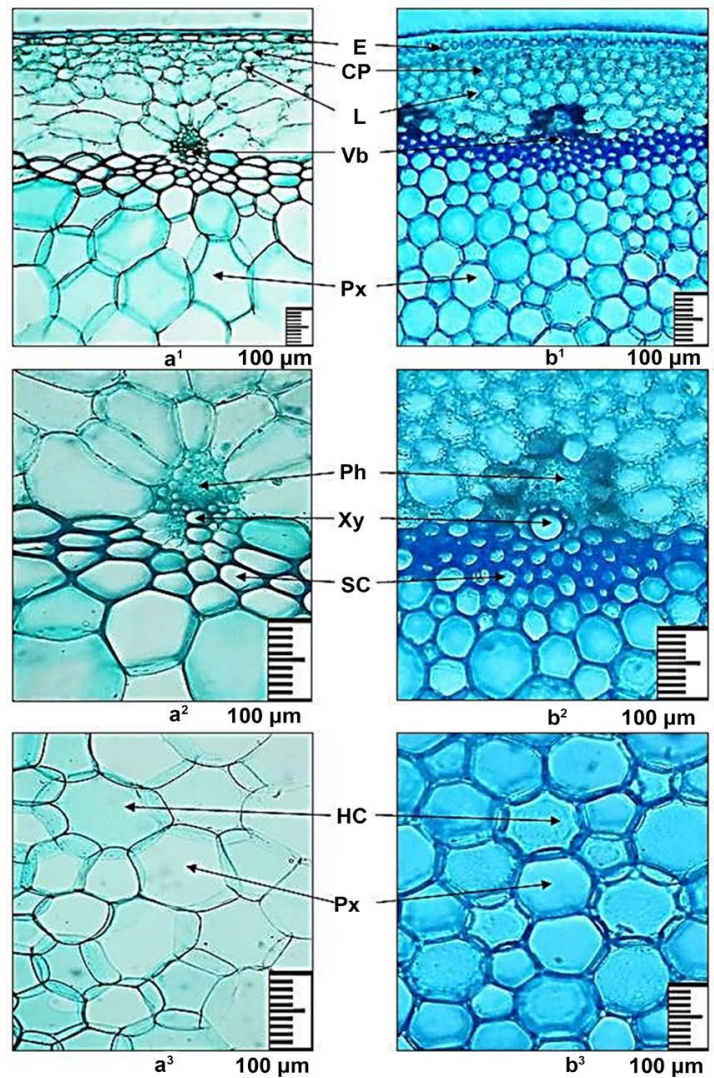

Figure 1. Anatomical structure of the inflated part of the stem (fistular) A. praemixtum in conditions of nature $\left(\mathrm{a}^{1}\right)-\left(\mathrm{a}^{3}\right)$ and introductions $\left(\mathrm{b}^{1}\right)-\left(\mathrm{b}^{3}\right):\left(\mathrm{a}^{1}\right),\left(\mathrm{b}^{1}\right)$ scheme and detail; $\left(\mathrm{a}^{2}\right),\left(\mathrm{b}^{2}\right)$ vascular bundle and sclerenchyma; $\left(a^{3}\right),\left(b^{3}\right)$ core. Magnification-100 micron. Legend: HD-hydrocytic cells, CP-cortex parenchyma, Xy-xylem, L-lacteals, Vb-vascular bundle, Px-parenchyma, SC-sclerenchyma, $\mathrm{Ph}$-phloem, E-epidermis. 
Table 1. Quantitative indicators of the vegetative organs of Allium praemixtum in two different environmental conditions $(\mathrm{n}=30)$.

\begin{tabular}{|c|c|c|c|}
\hline \multicolumn{2}{|c|}{ Indicators } & \multirow{2}{*}{$\begin{array}{c}\text { Navoi region } \\
54.9 \pm 0.37\end{array}$} & \multirow{2}{*}{$\begin{array}{c}\text { Tashkent } \\
\underline{42.8} \pm 0.39\end{array}$} \\
\hline & inflated part of stem (fistular) & & \\
\hline \multirow[t]{3}{*}{ Height epidermal cells, $\mu \mathrm{m}$} & stem & $\underline{32.7} \pm 0.47$ & $48.7 \pm 0.53$ \\
\hline & pedicel & $\underline{18.6} \pm 0.09$ & $39.8 \pm 0.33$ \\
\hline & inflated part of stem (fistular) & $\underline{23.1 \pm 0.18}$ & $20.3 \pm 0.08$ \\
\hline \multirow{2}{*}{$\begin{array}{l}\text { The thickness of the outer } \\
\text { wall of the epidermis, } \mu \mathrm{m}\end{array}$} & stem & $\underline{18.6} \pm 0.13$ & $12.9 \pm 0.07$ \\
\hline & pedicel & $5.1 \pm 0.04$ & $11.4 \pm 0.09$ \\
\hline \multirow{3}{*}{ Submergencestomata, $\mu \mathrm{m}$} & inflated part of stem (fistular) & $19.2 \pm 0.09$ & $22.8 \pm 0.12$ \\
\hline & stem & - & $\underline{19.5} \pm 0.21$ \\
\hline & inflated part of stem (fistular) & $126.3 \pm 1.13$ & $\underline{45.6} \pm 0.37$ \\
\hline \multirow{3}{*}{$\begin{array}{l}\text { Diameter cortex } \\
\text { parenchyma, } \mu \mathrm{m}\end{array}$} & stem & $\underline{57.5} \pm 0.61$ & $73.8 \pm 0.65$ \\
\hline & pedicel & $\underline{25.5} \pm 0.31$ & $40.5 \pm 0.53$ \\
\hline & inflated part of stem (fistular) & $222.5 \pm 2.31$ & $102.3 \pm 1.10$ \\
\hline \multirow{2}{*}{$\begin{array}{l}\text { Core: diameter } \\
\text { parenchyma, } \mu \mathrm{m}\end{array}$} & stem & $\underline{68.1} \pm 0.72$ & $96.6 \pm 0.87$ \\
\hline & pedicel & $33.5 \pm 0.47$ & $\underline{28.5} \pm 0.21$ \\
\hline \multirow{2}{*}{ Diameter lacteal, $\mu \mathrm{m}$} & inflated part of stem (fistular) & $35.1 \pm 0.21$ & $36.5 \pm 0.41$ \\
\hline & stem & $24.3 \pm 0.17$ & $42.7 \pm 0.56$ \\
\hline \multirow{3}{*}{$\begin{array}{l}\text { The diameter of the vessels in } \\
\text { the conductive beams, } \mu \mathrm{m}\end{array}$} & inflated part of stem (fistular) & $31.2 \pm 0.28$ & $36.6 \pm 0.29$ \\
\hline & stem & $\underline{15.6} \pm 0.09$ & $31.5 \pm 0.41$ \\
\hline & pedicel & $10.5 \pm 0.07$ & $12.5 \pm 0.09$ \\
\hline
\end{tabular}

Note: Values that are significantly different from those of the nature and introduction of these species are underlined.

There are large, elongated cells of the lining around the lacteal. Vascular bundles are located under the cortex parenchyma and over the sclerenchyma. Vascular bundles have very large and small vessels, phloem and xylem. In the Vascular bundles there are 2 large and 7 - 8 small vessels with a diameter of $31.2 \pm$ $0.28 \mu \mathrm{m}$ (Figure 1; Table 1).

The coreis extensive, the parenchymal cells are thin-walled, rounded-oval, and there are hydrocytic cells in it. Due to the destruction of parenchymal cells, a large cavity is formed in the central part of the core, which occupies all the internal parts of the fistular (Figure 1; Table 1).

The structure of the stem: On the cross section of the stem rounded shape. The structure of the parenchymal-bundle type. The epidermis consists of one row of cells, rounded, with a small diameter of $54.9 \pm 0.37 \mu \mathrm{m}$ in height. The cuticle of the epidermis is slightly wavy, more thickened $18.6 \pm 0.13 \mu \mathrm{m}$. Under the epidermis, there are 5 - 6 rows of cortex parenchyma, with a diameter of 57.5 $\pm 0.61 \mu \mathrm{m}$. Between the cortex parenchyma are less pronounced few lacteals, of relatively small size $24.3 \pm 0.17 \mu \mathrm{m}$, which are not tightly localized. There are 
cells with brown contents around the lacteals.Vascular bundles are located under the cortex parenchyma and over the sclerenchyma. Vascular bundles have very large and small vessels, phloem and xylem. In the Vascular bundles there are 2 large and 3 - 4 small vessels (Figure 2; Table 1).

The structure of the pedicel: The pedicle on the cross section is markedly rounded-costal. The structure of the parenchymal-bundle type. The epidermis consists of a single row of cells, oval in shape, with a small diameter of $18.6 \pm$ $0.09 \mu \mathrm{m}$ in height. The walls of the outer epidermis are thin $-5.1 \pm 0.04 \mu \mathrm{m}$. Under the epidermis there is a 4 - 5 row, round-oval, small $(25.5 \pm 0.31 \mu \mathrm{m})$ and thick-walled cortex parenchyma (Figure 3; Table 1).

The cortex parenchyma is detached from the central cylinder by a sclerenchyma ring. Thin-walled sclerenchyma: In the central cylinder there are 3 vascular bundles. Vascular bundles are not sclerified, which consist of phloem and xylem (Figure 3; Table 1).

The vessels are small, thick-walled $5-6$. Most of the pedicel is occupied by sclerenchymal cells (Figure 3; Table 1).

The structure of the inflated part of stem (fistular) of $A$. praemixtum in the conditions of introduction in the Tashkent Botanical Garden: On the crosssection of a round shape. The structure of the parenchymal-bundletype: The epidermis is single-row, slightly tangentially-elongated, densely located. The walls of the outer epidermis are relatively thick-20.3 $\pm 0.08 \mu \mathrm{m}$, the cuticle is slightly wavy.

The stomata are numerous, immersed $-22.8 \pm 0.12 \mu \mathrm{m}$ reach half the height of the epidermal cells. The form of the epidermal cells is elongated-42.8 \pm 0.39 $\mu \mathrm{m}$ in height, the side walls are thin.

Under the epidermis, there is 7 - 8 inline, round-oval, chlorophyll, small-cell cortex parenchyma with a diameter of $45.6 \pm 0.37 \mu \mathrm{m}$, under them are numerous large lacteals with a diameter of $36.5 \pm 0.41 \mu \mathrm{m}$, which are localized through each 2 - 4 cortex parenchyma. There are cells with brown contents around the crawlers. Vascular bundles of different sizes are located under the lacteals in the periphery. Vascular bundles have very large and small vessels, phloem and xylem. In vascular bundles there are 10 - 11 large and small vessels with a diameter of $36.6 \pm 0.28 \mu \mathrm{m}$ (Figure 1; Table 1).

The structure of the stem: On the cross section of the stem rounded shape. The structure of the parenchymal-bundle type.

The epidermis is single-row, tangentially elongated $48.7 \pm 0.53 \mu \mathrm{m}$ in height, densely located. The walls of the outer epidermis are relatively thick-walled-12.9 $\pm 0.07 \mu \mathrm{m}$, the cuticle is slightly wavy.

The stomata are numerous, immersed $-19.5 \pm 0.21 \mu \mathrm{m}$ reach half the height of the epidermal cells. Under the epidermis there is a 1 - 2 row tangentially elongated chlorophyll, small-cell cortex parenchyma with a diameter of $73.8 \pm$ $0.65 \mu \mathrm{m}$, under them are numerous large lacteals with a diameter of $42.7 \pm 0.56$ $\mu \mathrm{m}$, which are localized through each $2-4$ cortex parenchyma. There are cells with brown contents around the lacteals (Figure 2; Table 1). 

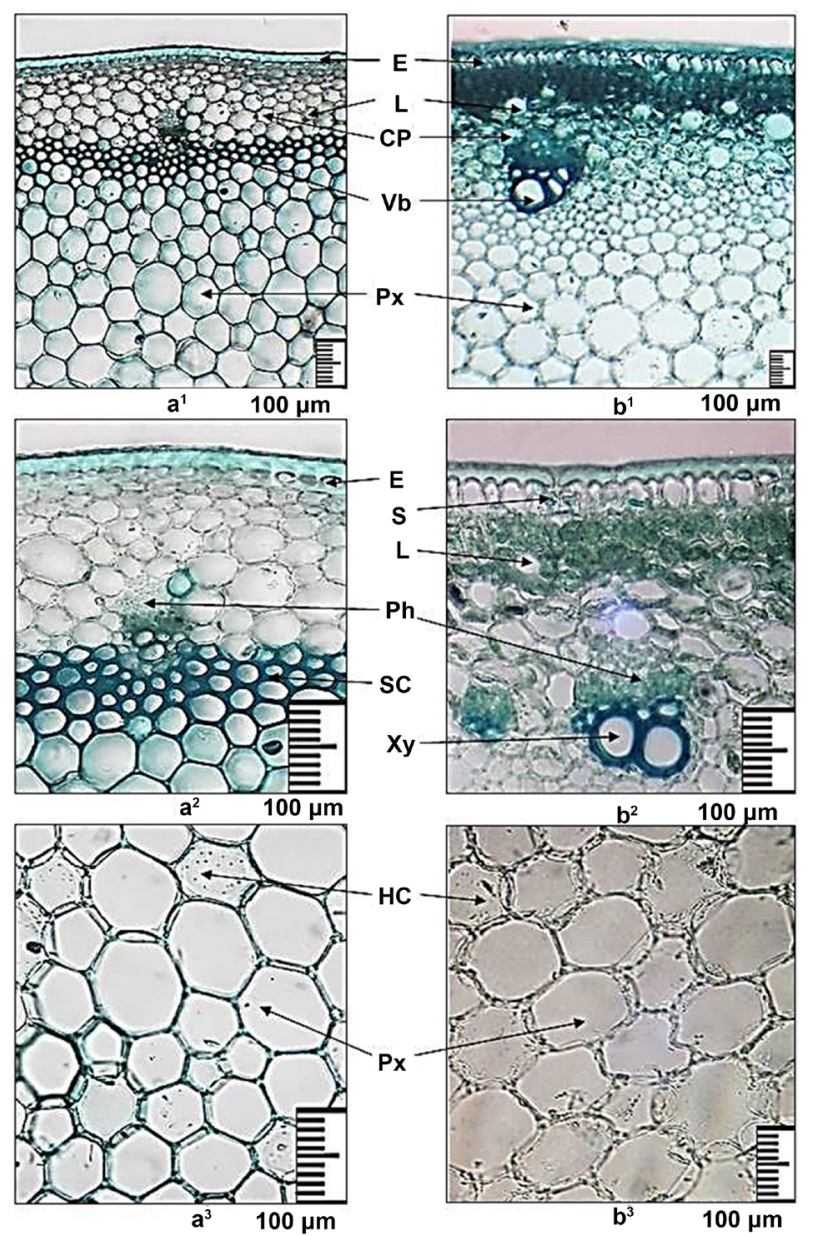

Figure 2. Anatomical structure of the stem A. praemixtum in conditions of nature $\left(\mathrm{a}^{1}\right)-\left(\mathrm{a}^{3}\right)$ and introductions $\left(\mathrm{b}^{1}\right)-\left(\mathrm{b}^{3}\right):\left(\mathrm{a}^{1}\right)$, $\left(b^{1}\right)$ scheme and detail; $\left(a^{2}\right),\left(b^{2}\right)$ vascular bundle and sclerenchyma; $\left(a^{3}\right),\left(b^{3}\right)$ core. Magnification-100 micron. Legend: HD-hydrocytic cells, CP-cortex parenchyma, S-stoma, Xy-xylem, L-lacteals, Vb-vascular bundle, Px-parenchyma, SC-sclerenchyma, Ph-phloem, E-epidermis.

Vascular bundles of different sizes are located under the lacteals in the periphery. Vascular bundles have very large and small vessels, phloem and xylem. In the Vascular bundles there are 2 large and 6 small vessels with a diameter of 31.5 $\pm 0.41 \mu \mathrm{m}$ (Figure 2; Table 1).

The structure of the pedicel: The pedicle on the cross section is markedly rounded-costal. The structure of the parenchymal-bundle type. The epidermis is single-row, the cells of its round-oval shape are $39.8 \pm 0.33 \mu \mathrm{m}$ in height, however, some epidermal cells located under the ribs are conical in shape. The outer wall of the epidermis is not thickened $11.4 \pm 0.09 \mu \mathrm{m}$, covered with a thin layer of the cuticle, the inner wall is thin, the surface of the cuticle is slightly wavy. Under the epidermis there is a $4-5$ row round-oval, thin-walled cortex parenchyma. The cortex parenchyma is detached from the central cylinder by a sclerenchyma ring (Figure 3; Table 1). 


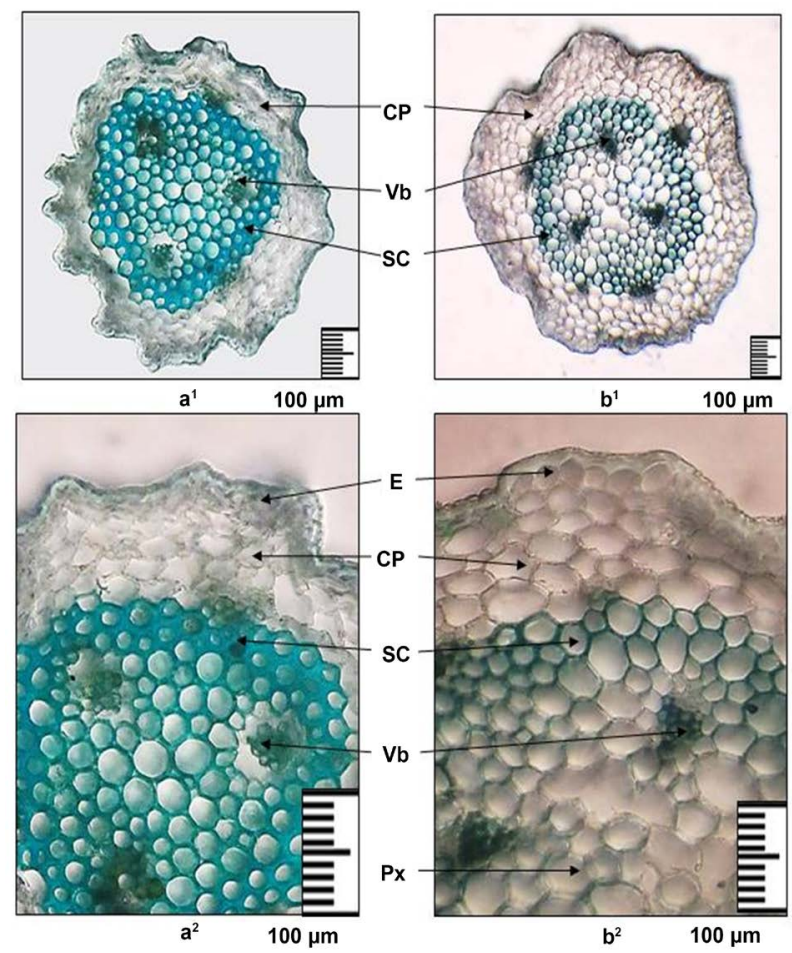

Figure 3. Anatomical structure of the pedicel $A$. praemixtum in conditions of nature $\left(\mathrm{a}^{1}\right)-\left(\mathrm{a}^{2}\right)$ and introductions $\left(\mathrm{b}^{1}\right)-\left(\mathrm{b}^{2}\right):\left(\mathrm{a}^{1}\right)$, $\left(b^{1}\right)$ scheme; $\left(a^{2}\right),\left(b^{2}\right)$ vascular bundle and sclerenchyma; Magnification-100 micron. Legend: CP-cortex parenchyma, Vb-vascular bundle, Px-parenchyma, SC-sclerenchyma, E-epidermis.

Thin-walled sclerenchyma. In the central cylinder there are 3 vascular bundles. Vascular bundles are not sclerified, which consist of phloem and xylem. The vessels are small, thick-walled $6-7$, with a diameter of $12.5 \pm 0.09 \mu \mathrm{m}$. Most of the pedicel is parenchymal tissue. The parenchymal cells are thin-walled, rounded-oval (Figure 3; Table 1).

Thus, when studying the structure of the vegetative organs of $A$. praemixtum in two different ecological conditions (in nature and introductions), xeromorphic and mesomorphic characters were first revealed. Xeromorphic signs: thickened outer wall of the epidermis; small, numerous epidermal, parenchymal cells; small, numerous, immersed stomata; thick-walled sclerenchyma cells; small and numerous vessels in vascular bundles (Figure 4).

Mesomorphic signs: thin-walled, large, few epidermal and parenchymal cells; not numerous, immersed stomata; large intermediate sclerenchymal cells; large and few vessels in vascular bundles (Figure 4).

\section{Conclusion}

The identified structural diagnostic features of the vegetative organs are species-specific, and show the adaptation of this species to the habitat conditions. Adaptive mesomorphic and xeromorphic signs are revealed. The species that grows in natural conditions is dominated by more xeromorphic signs, 


\section{$\square$ mesomorphic signs $\quad \square$ xeromorphic signs}

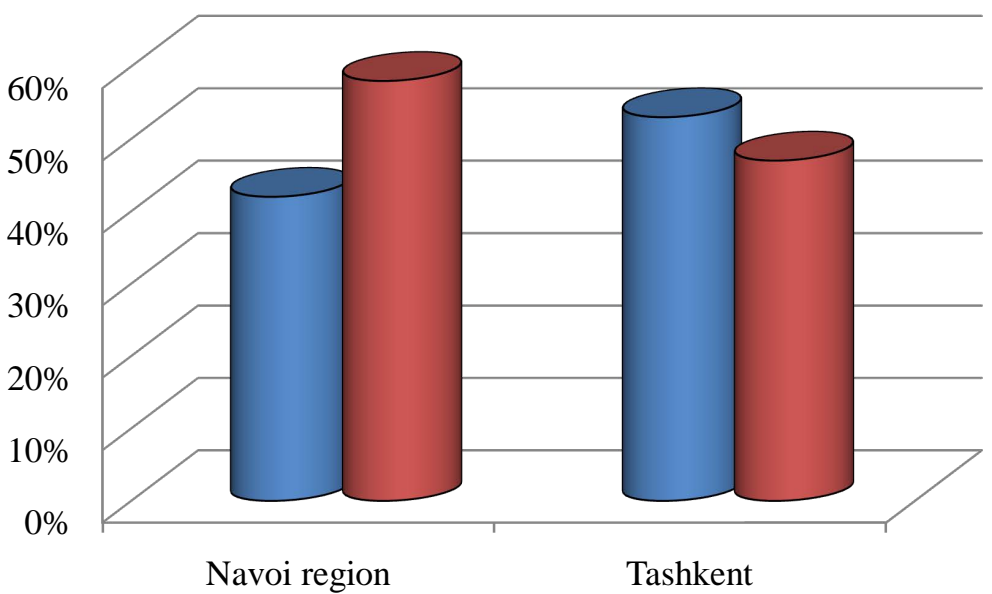

Figure 4. Correlation adaptive mesomorphic and xeromorphic signs ( $\mathrm{n}=19$ ) of the vegetative organs Allium praemixtum different ecological habitats conditions (nature and introduction).

which indicates the rarity of this species. In a species growing under the conditions of introduction of the Tashkent Botanical Garden, mesomorphic signs predominate, which shows that the species is adapted to the altered conditions.

\section{Acknowledgements}

The current research is done under the project BA-FA-F5-008 "Scientific basis for the preservation of the gene pool of ex situ rare endemic species of Uzbekistan's flora and the biology of their reproduction".

\section{Conflicts of Interest}

The authors declare no conflicts of interest regarding the publication of this paper.

\section{References}

[1] Fritsch, R.M., Blattner F.R. and Gurushidze M. (2010) New Classification of Allium L. subg. Melanocrommyum (Webb \& Berthel.) Rouy (Alliaceae) Based on Molecular and Morphological Characters. Taxon, 49, 145-220. https://doi.org/10.2307/1223113

[2] Agardh, J.G. (1858) Theoria Systematic Plantarum. Lund, 404.

[3] Williams, C. (1975) Biosystematics of the Monocotyledoneae-Flavonoid Patterns in leaves of the Liliaceae. Biochemical Systematics and Ecology, 3, 229-244. https://doi.org/10.1016/0305-1978(75)90007-1

[4] Takhtajyan, A.L. (1987) The System of Magniophytes. Science, Leningrad, 439. (In Russian)

[5] Vvedensky, A.I. (1935) Genus Allium L. Flora of the USSR. Academy of Sciences of the USSR, Leningrad, 112-274. (In Russian)

[6] Ibragimov, F.I. and Ibraghimova, V.S. (1960) Essential Medicines of Chinese Medi- 
cine. Moscow, 115-135.(In Russian)

[7] Khassanov, F.O. and Rakhimova, N. (2016) Red Book of the Republic of Uzbekistan. Chinor ENK, Tashkent, 206. (In Russian)

[8] Shomurodov, Kh.F., Rakhimova, T.T., Adilov, B.A., et al. (2018) Cenopopulations of Rare and Endangered Plant Species of remnant Kyzylkum Lowlands. Institute of Botany, Tashkent, 6-28. (In Russian)

[9] Duschanova, G.M. (2016) Adaptive Features of Vegetative Organs of Species of the Genus Climacoptera Botsch. (Chenopodiaceae) in Connection with Halophytic. Author's Abstract of the Thesis of Doctor of Biological Sciences, Tashkent, 35-36. (In Russian)

[10] Esau, K. (1969) Anatomy of Plants. Mir, Moscow, 138-416. (In Russian)

[11] Kiseleva, N.S. (1971) Anatomy and Morphology of Plants. Higher School, Minsk, 89-119. (In Russian)

[12] Barykina, R.P. and Chubatova, N.V. (2005) A Large Workshop on the Ecological Anatomy of Flowering Plants. Association of Scientific Publications, Moscow, 77. (In Russian)

[13] Zaitsev, G.N. (1991) Mathematics in Experimental Botany. Science, Moscow, 296. (In Russian) 